\title{
WATER, FOOD AND SUSTAINABLE LIFESTYLE
}

\author{
Ciprian-Beniamin Benea \\ Adina Secară-Oniţa ${ }^{2}$
}

DOI: https://doi.org/10.31410/ERAZ.2019.285

\begin{abstract}
Central points of this paper are man and the environment. There are presented some aspects of the unsustainable practices related to agriculture and food production, and how last century's practices had negatively influenced our welfare due to a too chemical agriculture, soil erosion, water waste, diseases, and finally unhappiness. There are mentioned all three water components used to sustain present day economic-social system-green, blue, and grey water - and the ways to reduce humankind's impact upon environment together with rising its welfare, happiness and environmental sustainability. In the conclusion, there are mentioned the benefits connected to a more friendly way of interacting with nature while we are searching for a healthier food, water and air.
\end{abstract}

Keywords: Democracy, food, environment, happiness, soil erosion, water.

\section{OVERVIEW}

T ife means movement and energy; and energy means there must be a source for it. Food and water are key-components of life and main energy providers for living organisms. But not all food and water production and consumption are sustainable. There are food production processes which are not sustainable from both production, and consumption point of view. Chemical fertilizers, pesticides, and other chemicals used in modern-type agriculture, to stimulate higher yield per surface of land, come with environmental costs, soil erosion and water pollution. More than needed food for individuals comes with higher economic costs and lower living standard due to medical problems.

The production of any commodity involves the consumption of water, and the product incorporates water, which we do not see; there are peculiarly virtual water and water footprint which are brought into attention here. Water footprint measures the quantity of water used to produce all goods and services used by one individual, or by the population of a specific country [1]. This water has three components: green, blue, and grey. Green water regards the rain water, while the blue water refers to surface water (from rivers, dams, impoundments, other types of catchments) and ground water (which is extracted, pumped, and transferred toward production places).

Grey water indicates the volume of water needed to absorb the load of pollutants and chemicals resulted due to agricultural and industrial production processes, while maintaining agreed ambient water quality standards [2].

While water footprint denotes the amount of this resource which is consumed, virtual water regards the needed water to produce something. As a result of agricultural activity, and of resulted

1 University of Oradea, Faculty of Economics, Oradea, Romania, str. Universitatii, no. 1

2 University of Oradea, Faculty of Economics, Oradea, Romania, str. Universitatii, no. 1 
food production processes in food industry, there is a highly connected chemical industry to natural environment and water resources.

The promoted reason for public acceptance of such a strategy is the higher yield per unit of land. But this comes with higher water consumption (due to irrigation) and a higher chemicalization of land (due to chemical fertilizers, herbicides, pesticides, and other chemicals used in agricultural processes). In the same time such a modern agriculture is connected to land concentration: it is not economic efficient to have modern agriculture of small land surfaces. Furthermore, to sustain it, there are needed huge water infrastructure projects, be they irrigation schemes, inter-basin transfers of water, and large dams. This can be spoken about as cowboy-economics, since economic powerful can invest in capital-intensive means while appropriating land and especially water, without any care about others' needs, and more important crossing limits of water systems, strongly hurting environment without bearing costs.

Even humankind witnessed a concrete revolution in the second part of past century [3], beginning with the $80^{\prime}$ 'there appeared different reports and analyses pointing to negative impacts of such huge infrastructure projects [4]. All these large projects - land concentration and corresponding water projects - favor capital concentration, rising power of global players in food industry face-to-face with local communities: this capital concentration could favor stealthily changing of political system from one close to local communities into a system with oligarchic (or even totalitarian) characteristics. And this negatively impacts upon a sustainable life-style, because freedom plays important role in man's happiness. Related to this aspect, a well-documented study related to water control, food production and strong-hand politics is made by Wittfogel [5].

\section{WATER AND LAND}

As the vital resources which provide health and energy for living organisms, air, water and land must be regarded and protected with highest attention. Their quality provides health which is the most important thing for a person's happiness. There could be no sustainable lifestyle in the absence of good air, water and food quality. The sickness, and as a consequence the unhappiness of a society is directly influenced by access to these three vital resources, and by their quality.

Currently [6], the world faces important water shortages, as renewable freshwater resource/capita has fallen to 5920.508 cubic meters (c.m.) in 2014 from 13,401.912 (c.m.), as it was in 1962.

The global demand for water has been increasing at a rate of some $1 \%$ yearly, this trend being triggered by population growth, economic development coupled with changing consumption patterns; furthermore, already nearly half the global population live in areas that are potentially water-scarce at least one month per year [7], and this population could increase to some 4.8-5.7 billion by 2050 .

Access to water will be a rising challenge in the years ahead, and the management of water resource will be one of the most difficult activities. Furthermore, main part of world soil resources, especially farmland, are in only fair, poor, and very poor condition, and this will only worsen in future, with negatively impacts on water cycling due to higher evaporation rates and a lower storage capacity for water in the soil. Changing precipitations pattern, and chemical components in soil due to modern agricultural practices, coupled with an increased soil runoff will overlap with higher erosion. All these are coming together with losing of some $65 \%$ of natural wetland worldwide because of human activity, especially in agriculture. 
As production of high-yield crops need chemical fertilizers and herbicides, it harms the organic character of soil through erosion. Soil is the biggest water reservoir humankind has, and reducing organic matter in soil determines a reduced capacity to hold moisture. As a matter of fact, presence of $4 \%$ of organic matter is soils (deep to 30 centimeters) means that this creates the capacity to retain some 640000 liters of water/hectare [8]. In the same time chemical fertilizers, destroying living process in the soil, make it more vulnerable to droughts and this is coupled with the production of nitrogen oxygen, a greenhouse gas which is more potent than carbon dioxide.

Furthermore, we can always look to the situation concerning Lake Turkana's gradual retreat from Ethiopian territory, which brought intense intertribal clashes, [9] and we should see this as an example with potential recurrent and repetitive situations in other parts of the world.

Taking all these into consideration, from chemicalization of agriculture - and as an extension of rivers and ground water reservoirs - to rising demand for food and water, there should be identified some solutions to provide a sustainable future. Agriculture must face projected increases in food demand through improvement of soils' efficiency coupled to pollution's reduction; in all these actions water is a key-factor [10]. This strategy could give way to a sustainable ecological intensification of food production, through increasing ecosystems capacities to provide goods for humankind needs, without harming, destruction or disturbance of the environment.

Soils and vegetation management are central in this action. Ways of land use must follow the path of lower disturbance, maintaining soil cover and the rotation of crops. Agricultural systems that rehabilitate and conserve ecosystem could be as productive as or even more productive than practices specific to second part of past century, but with significantly reduced costs for the environment, and as a consequence for the society at large. Better conserved environment means better food, better health, and as a result a higher living-standard. In this paradigm man and nature are the focal elements, distancing it from high-input systems which are connected to extremely mechanized agriculture, chemicals, irrigation and large reservoirs schemes, land and capital concentration, and as a consequence, of power concentration.

The main opportunities to increase yield/surface depend on rein-fed system which is the main system responsible for current family farming, bringing the highest benefits related to rising livelihood and poverty reduction. Departing from capital and land concentration towards this family-farming system would come together with a redistribution of economic gains from top to a lower, but a larger part of society. This distribution will come with rising importance of this part of population which will press for a more responsible type of citizenry. An atrophied, sick and stressed society will give away in face of a more responsible, healthy and happier citizenry.

\section{SUSTAINABLE LIFESTYLE}

It has to do primarily with each individual and as a consequence with all of us. A new attitude regarding our priorities and a more active life-style will help us to better understand the importance of a healthy environment for our happiness and for a higher quality of life.

How could one reasonably argue for a consumption of a 0 -calorie soft drink when its production, packing and transport involves calories' consumption? Since a diet soft drink has 1 calorie of energy, but there are needed in order to process it 600 calories, while for the production of the aluminum pack used to deliver it there being needed another 1600 calories [11], let alone trans- 
portation and delivery energy costs, what economic arguments are there from the consumption point of view? From ecological point of view, it is a total disaster: 1 calorie consumed to produce something which gives back only 0.00046 calories is completely unsustainable.

Furthermore, due to their size and complexity, complex food industrial conglomerates have already crossed over a sustainable threshold in a world where energy is more and more expensive, and its price faces high volatility. As argument it could be brought here to reader's attention the American food industry's situation. It needs 10 calories of energy to generate 1 calorie [12] retrieved in food with questionable quality, containing hidden dangers.

Rising incomes in emerging economies comes together with changing in dietary customs; more meat is demanded globally because of this trend; even close to 1 billion people experience chronic food insecurity, the main part of world's corn and soybean, and a growing share of wheat are directed to create food for animals, for meat production [13]. Grass fed animals has given place to grain-fed ones, rising in the same time the demand for antibiotics' use to artificially confined cattle; of all antibiotics sold in the US, $80 \%$ are directed to be administrated to healthy animals for growth-enhancing and prophylactic purposes [14]. This brings with it great environmental, animal-health and human-health disturbances.

In a no water-waste scenario, to feed one adult one day with a whole vegetarian diet, there are needed some 700 liters of water, while in case the dietary elements are $20 \%$ beef based, the amount of water to create that food doubles [15]. Put it simply but it an extreme framework, if every citizen would be vegetarian, water and food security and environment sustainability would be ensured [16].

We should aim at an equilibrium searching for an important reduction, not a total elimination of meat consumption; staying slim is healthy for individual and for the good of the Earth.

\section{CONCLUDING REMARKS}

Expanded at global scale a new attitude regarding ourselves and how we interact with the environment will bring gains which could be bigger than projected increases in global demand for water and food, directly contributing to conflict reduction among competing uses. This grass-root activity of society connected to food production and consumption will bring benefits such as:

- In economic arena: lower unemployment rate, increased self-sufficiency for a larger part of society in an increasingly unstable and unpredictable economic environment haunted by chronic (and repetitive) crises. A more local concentrated production and consumption places would press the economic system away from present day scenario; it will mean a lower energy need, which in present day is used to provide the functioning of global transportation networks for connection of distant production and consumption places, which is coupled to high capital concentration due to production (water projects and land concentration), storage (great storage capacities), chemicalization (chemical and seeds providers) and logistics (great transport enterprises especially, which in many cases act as geopolitical instruments to control distant economies and societies);

- In social and psychological arenas: rising citizens awareness regarding their life, restoration of traditional connections, regaining the central family's importance;

- In medical area: a healthier and happier people; 
- In environmental arena: better conservation of vital resources (air, water and land) coupled with an increased awareness and conservation related to environment's components (forests, fisheries, flora and fauna);

- In domestic politics: a larger and stronger middle class, and as a consequence a more stable and pleased society, more aware about its destiny, and as such, a stronger democratic political system. It could better reconcile society with itself, as it would distance it from a political regime with oligarchic characteristics toward a regime with stronger democratic components;

- In international arena: a lower risk for conflicts generated by the desire to gain access to water, food, and energy resources.

All these indicate that it could be possible to bring relief on environment and society together, creating in the meantime the possibilities for a happier and healthier individual enjoying a more stable society, a "greener" environment, and a more peaceful world.

\section{REFERENCES}

[1] Hoekstra, A.Y. (2003), "Virtual Water Trade: An Introduction", in Hoekstra, A.Y. Virtual Water Trade: Proceedings of the International Expert Meeting of Virtual Water Trade, Value of Water Research Report Series No. 12, UNESCO-IHE, Delft.

[2] Mekonnen, M.M. and Hoekstra, A.Y. (2010) "The Green, Blue and Grey Water Footprint of Crops and Derived Crop Products", Value of Water Research, Report Series No. 47, UNESCO-IHE, Delft.

[3] Sneddon, C. (2015) Concrete Revolution. Large Dams, Cold War Geopolitics, and the Bureau of Reclamation, University of Chicago Press, Chicago and London, pp. 1-22.

[4] World Commission on Large Dams (2000) Dams and Development. A New Framework for Decision-Making, Earthscan, London and Sterling, VA, pp. 74-93; 98-130.

[5] Wittfogel, K.A. (1963) Oriental Despotism. A Comparative Study of Total Power, Yale University Press, New Haven, CT.

[6] World Bank (2019): Renewable freshwater resources per capita https://data.worldbank.org/indicator/ER.H2O.INTR.PC?end=2014\&start=1998; accessed date March the 7-th 2019.

[7] The United Nations World Water Development Report (2018), UNESCO, Paris, p. 3.

[8] Shiva, V. (2016) Water Wars. Privatization, Pollution, and Profit, North Atlantic Books, Berkeley, p. xxiii.

[9] Chellaney, B. (2013) Water, Peace, and War. Confronting the Global Water Crisis, Rowman \& Littlefield Publishers, Inc., Lanham, Boulder, New York, Toronto, Plymouth UK, p. 190-191.

[10] The United Nations World Water Development Report (2018), UNESCO, Paris, p. 4.

[11] Georgescu, C. (2016) Pcumpăna României; Editura Christiana, Bucureşti, p. 21.

[12] Ibidem, p. 20.

[13] Chellaney, B. op. cit., p. 77.

[14] Ibidem, pp. 77-78.

[15] Wild, D. Francke; C.-J.; Menzli, P.; Schon, U. (2007) Water: A Market of the Future, Sustainable Asset Management, Zurich, p. 8.

[16] Chellaney, B. Op. cit., p. 79. 